\title{
Endothelin-1 Stimulates Contraction of Rat Glomerular Mesangial Cells and Potentiates $\beta$-Adrenergic-mediated Cyclic Adenosine Monophosphate Accumulation
}

Michael S. Simonson* and Michael J. Dunn ${ }^{\star \ddagger}$

${ }^{*}$ Departments of Medicine and ${ }^{\ddagger}$ Physiology and Biophysics, School of Medicine, Case Western Reserve University, Division of Nephrology, University Hospitals of Cleveland, Cleveland, Ohio 44106

\begin{abstract}
The newly isolated peptide, endothelin-1 (ET-1), is a potent pressor agent that reduces GFR and the glomerular ultrafiltration coefficient. Recent evidence demonstrates that ET-1 mobilizes intracellular $\mathrm{Ca}^{2+}\left(\left[\mathrm{Ca}^{2+}\right]_{i}\right)$ in glomerular mesangial cells by activating the phosphoinositide cascade. The present experiments were designed to examine whether ET-1 stimulates mesangial cell contraction and regulates the synthesis of $\mathrm{PGE}_{2}$ and $\mathrm{CAMP}$, which dampen vasoconstrictor-induced mesangial contraction. ET-1 ( $\geq 1 \mathrm{nM}$ ) reduced the cross-sectional area of rat mesangial cells cultured on three-dimensional gels of collagen type I. ET-1 also caused complex rearrangements of F-actin microfilaments consistent with a motile response. Contraction in response to ET-1 occurred only at concentrations that activate phospholipase $\mathbf{C}$, and contraction was unaffected by blockade of dihydropyridine-sensitive $\mathrm{Ca}^{2+}$ channels. Elevation of $\left[\mathrm{Ca}^{2+}\right]_{i}$ with ionomycin, to equivalent concentrations of $\left[\mathrm{Ca}^{2+}\right]_{i}$ achieved with ET-1, also reduced mesangial cell cross-sectional area. ET-1 (0.1 $\mu \mathrm{M})$ also evoked [ $\left.{ }^{3} \mathrm{H}\right]$ arachidonate release and a fivefold increase in $\mathbf{P G E}_{2}$ synthesis as well as increased synthesis of $\mathrm{PGF}_{2 \alpha}$ and small changes of TXB $_{2}$. ET-1 caused a minor increase in intracellular cAMP accumulation only in the presence of 3-isobutyl-1-methylxanthine. ET-1 also amplified CAMP production in response to isoproterenol. TPA and ionomycin, alone and in combination, failed to mimic the potentiating effect of ET-1; however, indomethacin blocked ET-1-induced potentiation of isoproterenolstimulated CAMP, which was restored by addition of exoge-

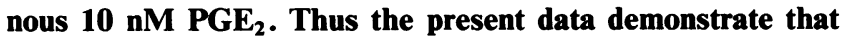
ET-1 stimulates mesangial cell contraction via pharmacomechanical coupling and activates phospholipase $A_{2}$ to produce $\mathrm{PGE}_{2}, \mathrm{PGF}_{2 \alpha}$, and TXB $\mathrm{TX}_{2}$. ET-1 also amplified $\beta$ adrenergicstimulated cAMP accumulation by a $\mathbf{P G E}_{2}$-dependent mechanism. (J. Clin. Invest. 1990. 85:790-797.) endothelium-derived mediators $\bullet$ prostaglandins $\bullet$ phospholipase $A_{2} \bullet$ adenylate cyclase $\bullet$ vasoconstriction
\end{abstract}

\section{Introduction}

Endothelin-1 (ET-1) ${ }^{1}$ is a member of a family of peptides synthesized by endothelial and other cell types in vitro and in vivo

Address reprint requests to Dr. Dunn, Department of Medicine, University Hospitals of Cleveland, 2074 Abington Road, Cleveland, $\mathrm{OH}$ 44106.

Received for publication 20 March 1989 and in revised form 27 October 1989.

1. Abbreviations used in this paper: AVP, arginine vasopressin; DHP,

J. Clin. Invest.

(c) The American Society for Clinical Investigation, Inc.

0021-9738/90/03/0790/08 \$2.00

Volume 85, March 1990, 790-797
(1-3). Endothelin peptides arise from at least three preproendothelin species, which after proteolysis yield different isoforms (ET-1, -2, and -3, [1-3]). ${ }^{2}$ ET-1 contracts diverse smooth muscle preparations in vitro $(1,3,4)$, and when injected in vivo $\mathrm{ET}-1$ is a potent vasoconstrictor $(1,3)$, particularly in the renal vasculature $(5-10)$.

Recent experiments demonstrate a role for ET- 1 in the control of glomerular hemodynamics. Miller et al. (8) and King et al. (9) found that ET-1 decreased both GFR and renal plasma flow; a disproportionate decline in renal plasma flow caused the filtration fraction to fall. Using micropuncture, Badr and co-workers (10) documented increased glomerular afferent and efferent arteriolar resistance and a dramatic decline in the ultrafiltration coefficient, $K_{f}$, in response to ET-1. Although the precise mechanism controlling $K_{\mathrm{f}}$ remains uncertain, the currently favored hypothesis is that contraction of mesangial cells, which are glomerular microvascular pericytes, decreases $K_{\mathrm{f}}$ by reducing filtration surface area (see 11-13 for review). We previously reported that ET-1 evokes two distinct patterns of $\mathrm{Ca}^{2+}$ signaling in cultured rat mesangial cells (14). ET-1 at 0.1-10.0 pM caused a modest but sustained elevation of $\left[\mathrm{Ca}^{2+}\right]_{\mathrm{i}}$ that depended on $\mathrm{Ca}^{2+}$ entry. In contrast, higher doses of ET-1 (0.1-100.0 $\mathrm{nM})$ caused a rapid, transient increase in $\left[\mathrm{Ca}^{2+}\right]_{i}$ followed by a lower, sustained phase (14). The transient phase of $\left[\mathrm{Ca}^{2+}\right]_{\mathrm{i}}$ correlated with activation of phospholipase $C$ and the release of inositol-1,4,5-trisphosphate, which mobilizes $\mathrm{Ca}^{2+}$ from intracellular stores (15). These data implicate activation of the phosphoinositide cascade as an initial event leading to endothelin-induced biological changes, possibly including contraction of mesangial cells via pharmacomechanical coupling.

Using cultured rat mesangial cells, the present experiments were designed to examine whether ET-1 causes mesangial cell contraction and stimulates synthesis of two negative feedback signals, prostaglandin $\mathrm{E}_{2}\left(\mathrm{PGE}_{2}\right)$ and cAMP, which dampen mesangial contraction $(11,12,16)$. Our experiments provide evidence that ET-1 (a) stimulates mesangial contraction which correlates with activation of the phosphoinositide cascade; $(b)$ increases $\left[{ }^{3} \mathrm{H}\right]$ arachidonate release and $\mathrm{PGE}_{2}, \mathrm{PGF}_{2 \alpha}$, and $\mathrm{TXB}_{2}$ synthesis; and $(c)$ amplifies $\beta$-adrenergic-stimulated cAMP accumulation via a $\mathrm{PGE}_{2}$-dependent mechanism.

\section{Methods}

Materials. Porcine ET-1 was from Peninsula Laboratories (Belmont, CA). Bovine dermal collagen type I was purchased from Collagen

dihydropyridine; DPBS, Dulbecco's PBS; IBMX, 3-isobutyl-1-methylxanthine; TPA, 12-tetradecanoyl phorbol 13-acetate.

2. The nomenclature for designating endothelin isoforms is that suggested by Drs. Masashi Yanigasawa and Tomah Masaki at a recent Endothelin Workshop held at the William Harvey Research Institute, London, England in December 1988. ET-1 refers to the 21 amino acid porcine and human sequence. 
Corp. (Palo Alto, CA). Arginine vasopressin (AVP), 12-tetradecanoyl phorbol 13-acetate (TPA), ionomycin, nifedipine, and Bay K 8644 were obtained from Calbiochem-Behring Corp. (La Jolla, CA). Rhodamine-phalloidin and fura-2 acetoxymethylester were from Molecular Probes (Grand Junction, OR). [5,6,8,9,11,12,14,15- $\left.{ }^{3} \mathrm{H}\right]$ Arachidonate $(85 \mu \mathrm{Ci} / \mathrm{mmol})$ was from New England Nuclear (Boston, MA). SQ29,548 was from Squibb Pharmaceuticals (Princeton, NJ). All other biochemicals were from Sigma Chemical Co. (St. Louis, MO).

Mesangial cell culture and contraction assays. Rat mesangial cell strains in passages 5-15, cultured and characterized as reported (17), were subcultured onto three-dimensional, type I collagen gels in LabTek (Nunc) culture slides for measurements of cell contraction. Type I collagen gels were prepared by mixing $8.0 \mathrm{ml}$ of $2.9 \mathrm{mg} / \mathrm{ml}$ collagen in $0.012 \mathrm{~N} \mathrm{HCl}, 1.0 \mathrm{ml}$ of $1 \mathrm{~N} \mathrm{NaOH}$, and $1.0 \mathrm{ml}$ of $10 \times$ Minimal Essential Medium, all from sterile solutions at $4^{\circ} \mathrm{C}$, and adjusting to pH 7.4. Aliquots $(1 \mathrm{ml})$ were plated into two-chamber Lab-Tek slides and gelation was initiated by warming to $37^{\circ} \mathrm{C}$ for $1 \mathrm{~h}$. Contraction was tested $24 \mathrm{~h}$ after subculture onto the collagen gel by incubating cells plus or minus agonists in Hanks' balanced salt solution containing 1.6 $\mathrm{mM} \mathrm{CaCl}, 0.8 \mathrm{mM} \mathrm{MgSO}, 10 \mathrm{mM}$ Hepes (pH 7.4), and $2 \mathrm{mg} / \mathrm{ml}$ fatty acid-free bovine serum albumin (HBSS-II), and the change in cross-sectional area over time was measured using computer-aided microscopy as previously described (17). A cell was scored positive for contraction with a decrease in cross-sectional area $\geq 7 \%$. The signifcance of responding cells was tested by Chi-squared analysis (18).

Staining of F-actin microfilaments. $24 \mathrm{~h}$ after subculture into fourchamber Lab Tek slides, mesangial cells were incubated with HBSS-II alone or with agonists for $30 \mathrm{~min}$ at $23^{\circ} \mathrm{C}$. To evaluate cytoskeletal arrangements, cells were rinsed, twice, with Dulbecco's PBS (DPBS), fixed with $0.5 \mathrm{ml} 3.7 \%$ formaldehyde in DPBS for $10 \mathrm{~min}$ at $23^{\circ} \mathrm{C}$, rinsed, twice, with DPBS, permeabilized with $0.5 \mathrm{ml} 0.2 \%$ Triton $\mathrm{X}-100$ in DPBS (vol/vol) for $1 \mathrm{~min}$ at $23^{\circ} \mathrm{C}$, and rinsed again, three times, with DPBS. Cells were then treated with $0.2 \mathrm{ml} 5.0 \mathrm{U} / \mathrm{ml}$ rhodamine-phalloidin for $30 \mathrm{~min}$ at $23^{\circ} \mathrm{C}$ on a rotary shaker in the dark. After rinsing, twice, with DPBS, cells were mounted under glycerol/ DPBS (1:1), sealed, and photographed using a Leitz microscope with a mercury lamp, epifluorescence illumination, and Kodak TMax film. The photomicrographs in Fig. 3 were taken with identical exposures and the prints developed under identical conditions so that semiquantitative comparisons of relative staining intensities can be made.

Measurements of $\left[\mathrm{Ca}^{2+}\right]_{i} .\left[\mathrm{Ca}^{2+}\right]_{i}$ was determined with the $\mathrm{Ca}^{2+}$. sensitive dye fura-2 (19). As reported $(14,20)$, confluent monolayers on plastic Aclar coverslips (Allied Engineered Plastics, Pottsville, PA) were loaded with $1 \mu \mathrm{M}$ fura-2 acetoxymethylester for $40 \mathrm{~min}$ at $37^{\circ} \mathrm{C}$ in RPMI 1640, then washed, twice, and incubated again for $20 \mathrm{~min}$ in fura-2 free RPMI to allow for intracellular dye cleavage. The coverslips were mounted in a quartz cuvette with $2 \mathrm{ml}$ of Krebs-Henseleit Hepes buffer, $\mathrm{pH} 7.4$, maintained at $37^{\circ} \mathrm{C}$ with constant stirring. $\left[\mathrm{Ca}^{2+}\right]_{\mathrm{i}}$ was determined by measuring fluorescence with a University of Pennsylvania Biomedical Instruments Group spectrofluorimeter set at $339 \mathrm{~nm}$ excitation and $500 \mathrm{~nm}$ emission. Fluorescence measurements were converted to $\mathrm{Ca}^{2+}$ concentrations by determining maximal fluorescence $\left(F_{\max }\right)$ with $10-40 \mu \mathrm{M}$ ionomycin, followed by minimal fluorescence $\left(F_{\min }\right)$ with $7.5 \mathrm{mM}$ EGTA, $60 \mathrm{mM}$ Tris, $\mathrm{pH} 10.5(14,20)$. The following formula was then used: $\left[\mathrm{Ca}^{2+}\right]_{i}=K_{d}\left(\mathrm{~F}-\mathrm{F}_{\min } / \mathrm{F}_{\max }-\mathrm{F}\right), K_{d}$ for fura-2 $=224 \mathrm{nM}$ (19). Autofluorescence by the cells or agonists was negligible.

$\left[{ }^{3} \mathrm{H}\right]$ Arachidonate release and prostaglandin synthesis. For measuring $\left[{ }^{3} \mathrm{H}\right]$ arachidonate release, cells in six-well plates were incubated for $20 \mathrm{~h}$ with $1 \mu \mathrm{Ci} / \mathrm{ml}\left[{ }^{3} \mathrm{H}\right]$ arachidonate in RPMI 1640 medium with $17 \%$ fetal bovine serum. Incorporation into cellular lipid was $\geq 85 \%$ of added $\left[{ }^{3} \mathrm{H}\right]$ arachidonate. The labeling media was aspirated and the cells washed, three times, at 5-min intervals with HBSS-II. After the final wash agonists were added and $0.2-\mathrm{ml}$ aliquots of buffer were removed without replacement at the indicated times. Counts were corrected for volume, and counts at time 0 were subtracted; all conditions were measured in duplicate wells. For measurements of prostaglandin synthesis, subconfluent monolayers in 12-well plates $\left(4 \mathrm{~cm}^{2}\right.$ / well) were washed, twice, with $1 \mathrm{ml}$ RPMI 1640 medium. Incubations were in $0.5 \mathrm{ml} \mathrm{RPMI} 1640$ at $37^{\circ} \mathrm{C}$ in $5 \% \mathrm{CO}_{2} / 95 \%$ air for $15 \mathrm{~min}$, after which the supernates were immediately collected and frozen at $-40^{\circ} \mathrm{C}$. All conditions were in duplicate. Cellular protein was measured by the method of Bradford (21). Immunoreactive $\mathrm{PGE}_{2}, \mathrm{PGF}_{2 \alpha}$, and $\mathrm{TXB}_{2}$ were measured by RIA as previously described in this laboratory (17). All compounds used were checked independently for interference in the assays. Eicosanoid biosynthesis was corrected for total cellular protein per well and expressed as nanograms per milligram protein/ $15 \mathrm{~min}$.

Measurements of intracellular CAMP accumulation. Mesangial cell monolayers in 12-well plates were washed, twice, with RPMI 1640 medium, $10 \mathrm{mM}$ Hepes ( $\mathrm{pH} 7.4$ ). At time 0 , agonists were added in the same medium, or where indicated with $0.1 \mathrm{mM}$ 3-isobutyl-1-methylxanthine (IBMX). All conditions were in duplicate. After incubating for $3 \mathrm{~min}$ at $37^{\circ} \mathrm{C}$, the supernates were discarded and cyclic nucleotides extracted in $0.1 \mathrm{~N} \mathrm{HCl}$ for $3 \mathrm{~h}$ at $25^{\circ} \mathrm{C}(22)$. The extracts were stored frozen at $-40^{\circ} \mathrm{C}$. Cyclic AMP was detected, after acetylation, by RIA (20) and all compounds checked for interference with cAMP-antisera binding. Cellular protein was measured as described above and cAMP accumulation was expressed as $\mathrm{fmol} / \mu \mathrm{g}$ protein $/ 3 \mathrm{~min}$.

\section{Results}

ET-1 reduces cross-sectional area of mesangial cells. We assessed the contractile actions of ET-1 using mesangial cells cultured on three-dimensional collagen gels. When ET-1 was added at $0.1 \mu \mathrm{M}, 48 \%$ of cells demonstrated a marked reduction of cross-sectional area at $30 \mathrm{~min}$ (arrows in Fig. 1, Table I). Cross-sectional area in the responding cells fell by an average of $42 \%$, but in some cells reductions of $60-70 \%$ were seen. Contraction most often occurred along the long axis of the cell, although in many cells the cell body was also reduced (Fig. 1). Only $4.3 \%$ of control cells (i.e., HBSS-II alone) showed a significant (i.e., $>7 \%$ ) reduction in cross-sectional area (Fig. 1, Table I). 1 pM ET-1, which generates only a monophasic, slow but sustained elevation of $\left[\mathrm{Ca}^{2+}\right]_{i}(14)$, failed to induce mesangial cell contraction (Table I). In contrast, two concentrations of ET-1 (1.0 nM and $0.1 \mu \mathrm{M})$ that mobilize intracellular $\mathrm{Ca}^{2+}$ via activation of phospholipase $C(14)$ increased the percentage of contracted cells above control (Table I). Elevation of mesangial cell $\left[\mathrm{Ca}^{2+}\right]_{\mathrm{i}}$ with 1 and $10 \mu \mathrm{M}$ ionomycin, to similar concentrations of $\left[\mathrm{Ca}^{2+}\right]_{\mathrm{i}}$ mobilized by 0.01 and $0.1 \mu \mathrm{M} \mathrm{ET}-1$ (Fig. 2 and ref. 14), also reduced mesangial cell cross-sectional area in $25 \%$ and $67 \%$ of the cells, respectively (Table I). Contraction in response to ET-1 was unaffected by $10 \mu \mathrm{M}$ nifedipine, which blocks dihydropyridine (DHP)-sensitive $\mathrm{Ca}^{2+}$ channels. Further evidence that ET-1-induced contraction occurs independent of DHP-sensitive $\mathrm{Ca}^{2+}$ channels comes from experiments with Bay K 8644, a synthetic DHP Ca ${ }^{2+}$ channel agonist. Although Bay K 8644 stimulated a slow, sustained increase in $\left[\mathrm{Ca}^{2+}\right]_{i}$ in mesangial cells (Fig. 2), Bay K 8644 was unable to evoke a decrease in cross-sectional area in a significant percentage of mesangial cells compared to control incubations in HBSS-II (Table I). These data are consistent with ET-1-induced contraction of mesangial cells via pharmacomechanical coupling (i.e., activation of phospholipase $C$ ) and fail to support a role for DHP-sensitive $\mathrm{Ca}^{2+}$ channels.

As shown in Fig. 3, we examined the arrangement of actin microfilaments in mesangial cells treated with ET-1 and ionomycin (Fig. 3). In control cells incubated for $30 \mathrm{~min}$ in HBSSII alone, F-actin was assembled in long, linear microfilament bundles distributed evenly throughout the cytosol along the 


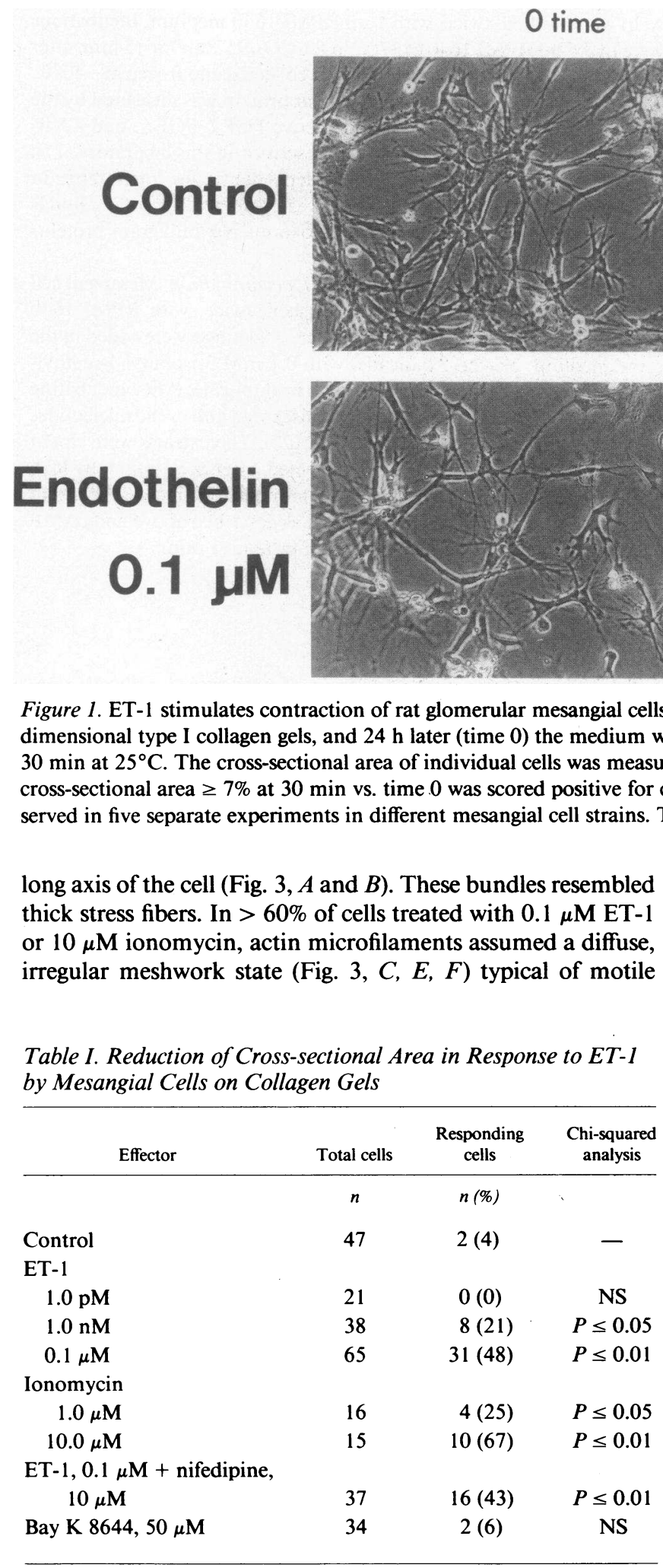

The reduction of cross-sectional area by individual mesangial cells was measured during a 30-min incubation with the indicated effectors and inhibitors as described in Methods. Any cell that reduced its cross-sectional area by $\geq 7 \%$ at $30 \mathrm{~min}$ was scored positive for contraction and considered a responding cell (17). Data are from three to four separate experiments, and chi-squared analysis compared the significance of responding vs. nonresponding cells for each condition (18).

long axis of the cell (Fig. 3, $A$ and $B$ ). These bundles resembled or $10 \mu \mathrm{M}$ ionomycin, actin microfilaments assumed a diffuse,

Table I. Reduction of Cross-sectional Area in Response to ET-1 by Mesangial Cells on Collagen Gels
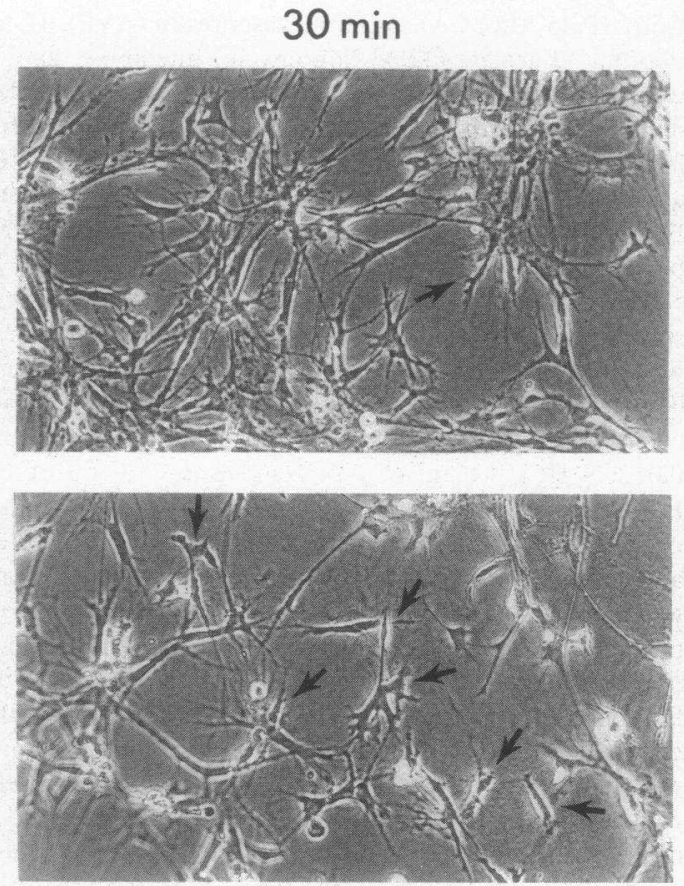

cells. As described in Methods, mesangial cells were subcultured onto threecross-sectional area $\geq 7 \%$ at 30 min vs. time .0 was scored positive for contraction. Arrows identify contractile cells. Similar results were ob-

cells. In general the amount of F-actin stainable with rhodamine-phalloidin was increased, even in the larger, flattened cells that failed to retract (Fig. $3 \mathrm{D}$ ). There were localized areas of intense condensation of actin microfilaments (single arrows, Fig. 3, $C, E, F)$, particularly in the retracted cells. Many cells treated with ET-1 or ionomycin elaborated membrane-associated condensations of $\mathrm{F}$-actin that formed bundles parallel to the plasma membrane (double arrows, Fig. 3, $C, E, F$ ). These rearrangements of actin microfilament bundles in mesangial cells incubated with ET-1 and ionomycin are consistent with an agonist-induced transition from stationary cells expressing stress fibers to motile cells elaborating a diffuse meshwork organization.

ET-1 caused release of $\left[{ }^{3} \mathrm{H}\right]$ arachidonate and synthesis of arachidonate metabolites. To test whether ET-1 stimulates release of arachidonic acid from membrane phospholipids, ET-1 was added to mesangial cells equilibrium labeled with $\left[{ }^{3} \mathrm{H}\right] \mathrm{ar}-$ achidonate. ET-1 $(0.1 \mu \mathrm{M})$ evoked a time-dependent increase in $\left[{ }^{3} \mathrm{H}\right]$ arachidonate release which plateaued by $10 \mathrm{~min}$ (Fig. 4 A). By $10 \mathrm{~min} \sim 0.3-0.5 \%$ of incorporated $\left[{ }^{3} \mathrm{H}\right]$ arachidonic acid was released by ET-1. Both the time course and magnitude of $\left[{ }^{3} \mathrm{H}\right]$ arachidonate release in response to ET-1 were similar to $\left[{ }^{3} \mathrm{H}\right]$ arachidonate release in the presence of $1.0 \mu \mathrm{M}$ AVP. ET-1 also increased production of immunoassayable $\mathrm{PGE}_{2}, \mathrm{PGF}_{2 \alpha}$, and $\mathrm{TXB}_{2}$ (Fig. $4 \mathrm{~B}$ ). ET-1 at $0.1 \mu \mathrm{M}$ generated a fivefold increase in $\mathrm{PGE}_{2}$ synthesis; by comparison, $0.1 \mu \mathrm{M}$ AVP stimulated a 2.7-fold increase. Activation of protein kinase $C$ by TPA has been reported to amplify phospholipase $A_{2}$ activity in cultured mesangial cells (23). In the present experiments, $0.1 \mu \mathrm{M}$ TPA alone doubled $\mathrm{PGE}_{2}$ production, and TPA had neither an additive nor a synergistic effect on ET-1or AVP-stimulated $\mathrm{PGE}_{2}$ production. That $0.1 \mu \mathrm{M}$ TPA was 

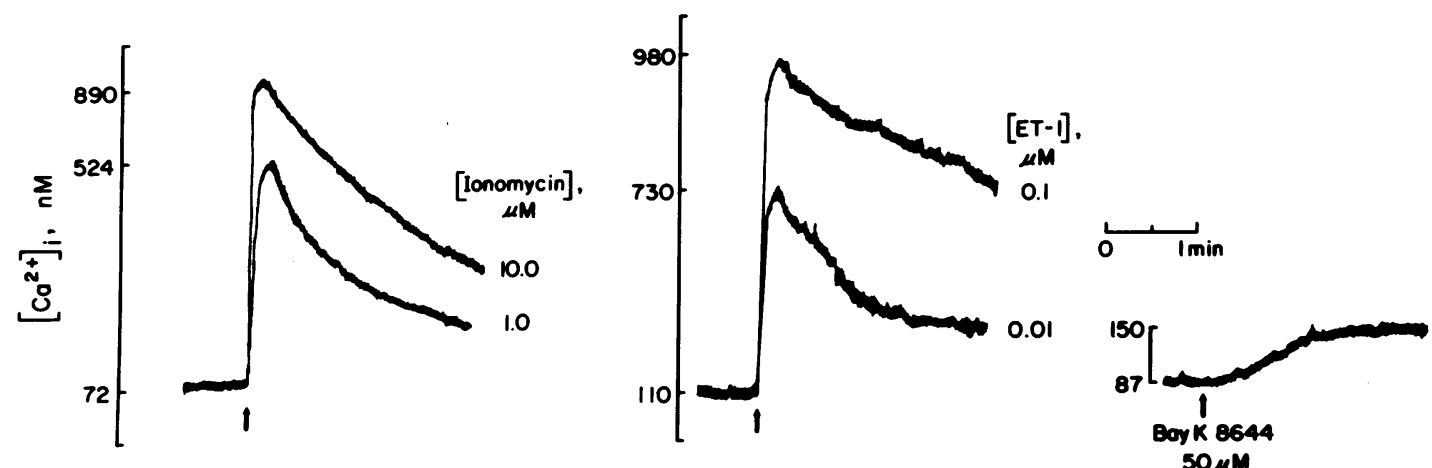

Figure 2. Ionomycin-, ET-1-, and Bay K 8644-induced changes in $\left[\mathrm{Ca}^{2+}\right]_{\mathrm{i}}$. Fura-2-loaded mesangial cell monolayers on plastic coverslips were

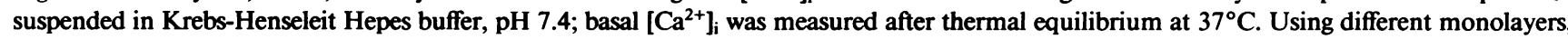
at the indicated times (arrows) 1.0 or $10 \mu \mathrm{M}$ ionomycin, 0.01 or $0.1 \mu \mathrm{M}$ ET-1, or $50 \mu \mathrm{M}$ Bay K 8644, were added to the rapidly stirred cuvettes. Tracings of ionomycin-induced $\left[\mathrm{Ca}^{2+}\right]_{i}$ were superimposed to facilitate comparison of the waveforms. The $\left[\mathrm{Ca}^{2+}\right]_{\mathrm{i}}$ waveforms evoked by

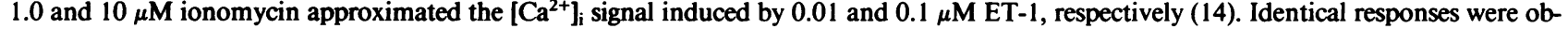
served for each condition in four different monolayers in separate experiments.
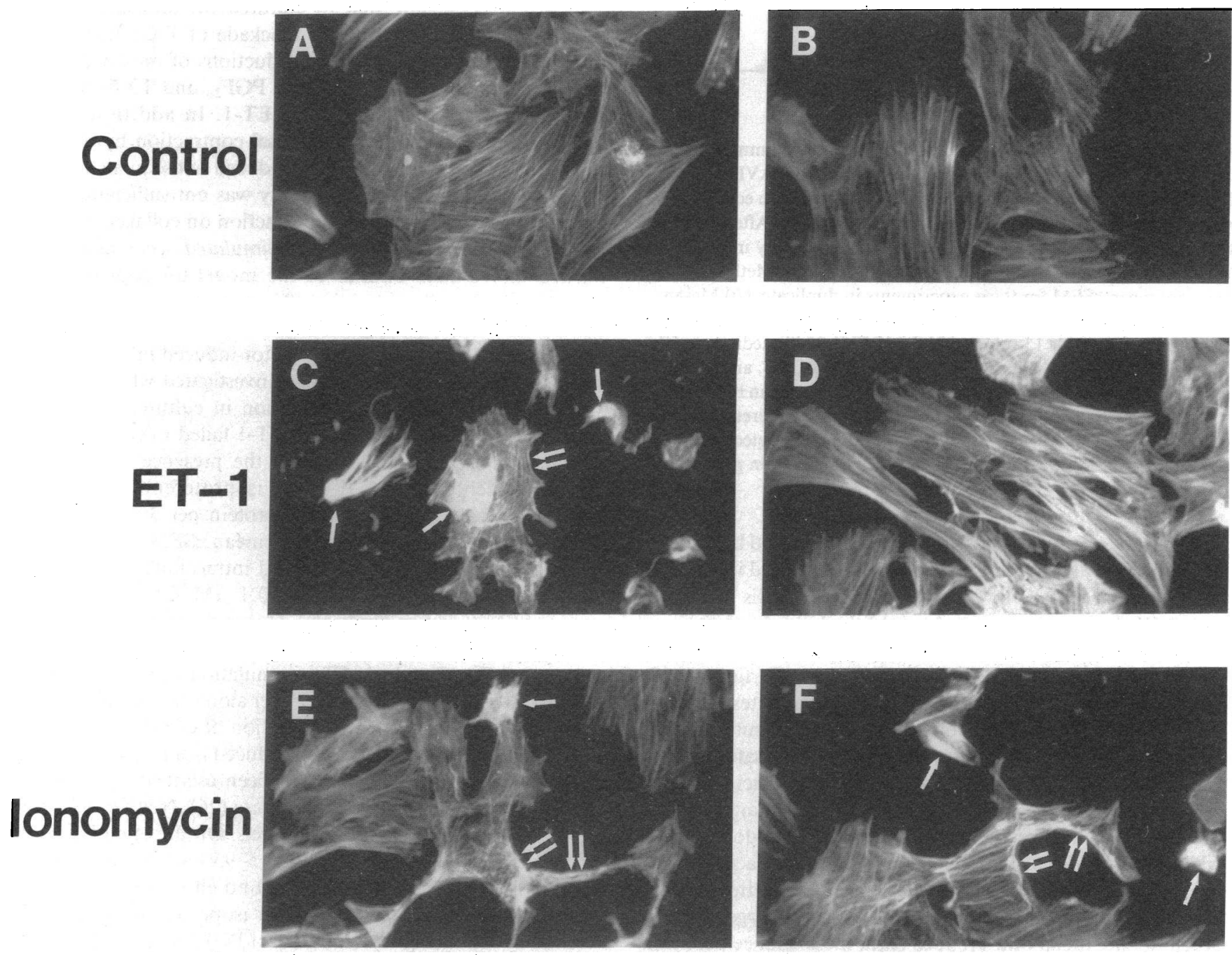

Figure 3. ET-1 and ionomycin cause complex rearrangements of F-actin microfilament bundles in mesangial cells. Cells on glass chamber slides were treated with HBSS-II $(A, B), 0.1 \mu \mathrm{M}$ ET-1 $(C, D)$, or $10 \mu \mathrm{M}$ ionomycin $(E, F)$ as described in Fig. 1 . The cells were then fixed in formaldehyde, permeabilized with Triton X-100, stained with rhodamine-phalloidin, and photographed under fluorescence microscopy as described in Methods. Specific properties of cell structure identified by arrows are described in the text. $\times 160$. 

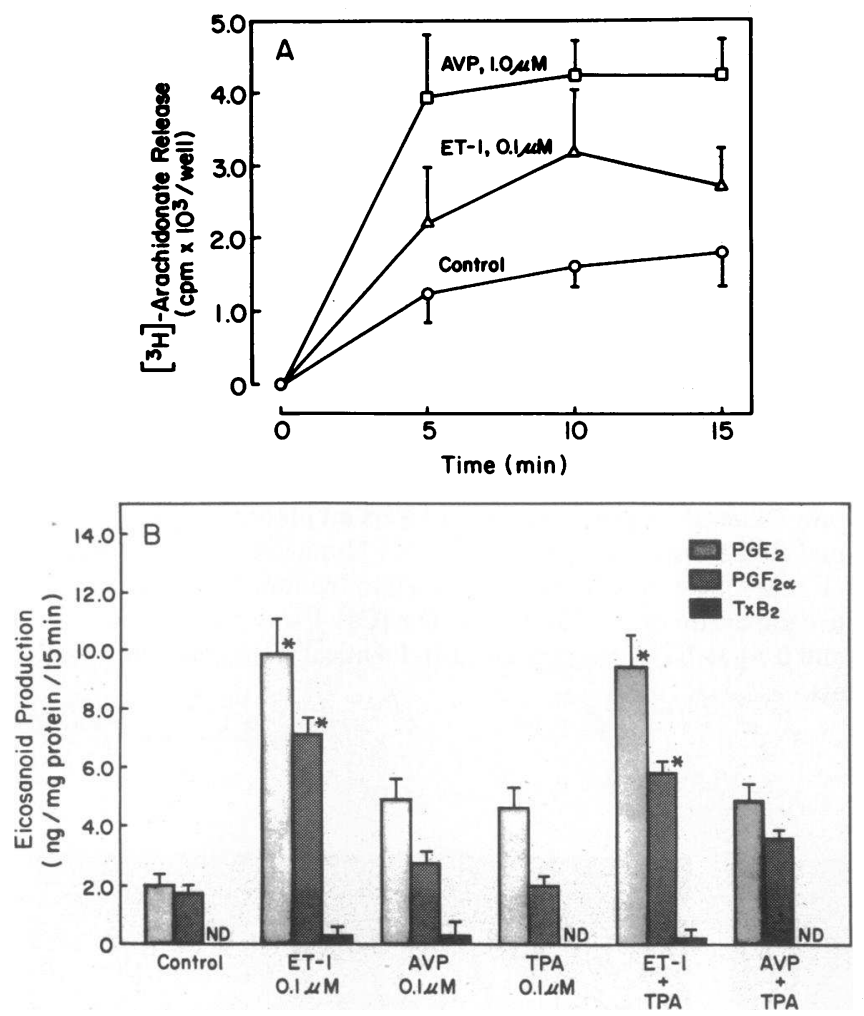

Figure 4. Release of $\left[{ }^{3} \mathrm{H}\right]$ arachidonate and synthesis of immunoreactive arachidonate metabolites in response to ET-1 and AVP. $(A)$ Mesangial cells at $80 \%$ confluency in six-well plates were equilibrium-labeled for $20 \mathrm{~h}$ with $\left.1 \mu \mathrm{Ci} / \mathrm{ml} \mathrm{[}{ }^{3} \mathrm{H}\right]$ arachidonate. After washing the cells, agonists were added and release of radioactivity into HBSSII was measured at the times indicated as described in Methods. Data are mean \pm SEM for three experiments in duplicate. $(B)$ Mesangial cells at $80 \%$ confluency in 12 -well plates were incubated with the effectors indicated for $15 \mathrm{~min}$ at $37^{\circ} \mathrm{C}$ in RPMI 1640 medium in $5 \%$ $\mathrm{CO}_{2} / 95 \%$ air. Release of immunoreactive $\mathrm{PGE}_{2}, \mathrm{PGF}_{2 \alpha}$, and $\mathrm{TXB}_{2}$ into the supernate was quantified by RIA. Data are mean \pm SEM for four to five experiments in duplicate. *Significantly different from control values $(P<0.05)$ by Student's $t$ test. ND, not detectable with a minimum detectable limit of $0.05 \mathrm{ng} \mathrm{TXB}_{2} / \mathrm{mg}$ protein per $15 \mathrm{~min}$.

sufficient to activate protein kinase $\mathrm{C}$ was suggested by concurrent experiments where TPA stimulated a threefold increase in $\left[{ }^{3} \mathrm{H}\right]$ thymidine uptake by quiescent mesangial cells incubated with $0.5 \%$ fetal bovine serum (unpublished observations).

$\mathrm{PGE}_{2}$ is thought to attenuate mesangial cell contraction whereas $\mathrm{PGF}_{2 \alpha}$ and $\mathrm{TXB}_{2}$ have contractile properties (11-12, 16). To determine if the arachidonate metabolites resulting from ET-stimulated phospholipase $A_{2}$ activity could mediate or regulate ET-induced contraction, we preincubated mesangial cells in the contraction assay with indomethacin to block cyclooxygenase and with SQ29,548, a thromboxane receptor blocker. A 10 -min preincubation with $10 \mu \mathrm{M}$ indomethacin, which blocks $\geq 95 \%$ of mesangial cyclooxygenase activity (24), modestly increased the percentage of cells exhibiting a significant decline in cross-sectional area (Table II), suggesting that arachidonate metabolites reduce basal mesangial cell contractility. Indomethacin, however, did not influence the reduction in cross-sectional area induced by $0.1 \mu \mathrm{M}$ ET-1 (Table II). Preincubation with $10 \mu \mathrm{M}$ SQ29,548 likewise had no effect in either control incubations or in incubations with ET-1 (Table
Table II. Effect of Indomethacin and SQ29,548

on the Reduction in Mesangial Cell Cross-sectional Area Induced by ET-I

\begin{tabular}{lccc}
\hline \multicolumn{1}{c}{ Effector } & $\begin{array}{c}\text { Total } \\
\text { cells }\end{array}$ & $\begin{array}{c}\text { Responding } \\
\text { cells }\end{array}$ & $\begin{array}{c}\text { Chi-squared } \\
\text { analysis }\end{array}$ \\
\hline & $n$ & $n(\%)$ & \\
Control & 24 & $2(8)$ & - \\
Indo, $10 \mu \mathrm{M} \rightarrow$ medium & 29 & $5(17)$ & $P \leq 0.05$ \\
Indo $\rightarrow$ ET-1, 0.1 $\mu \mathrm{M}$ & 54 & $24(44)$ & $P \leq 0.01$ \\
SQ29,548, $10 \mu \mathrm{M} \rightarrow$ medium & 24 & $3(13)$ & NS \\
SQ29,548 $\rightarrow$ ET-1 & 26 & $13(50)$ & $P \leq 0.05$ \\
& & & \\
\hline
\end{tabular}

Mesangial cells on type I collagen gels were incubated for $10 \mathrm{~min}$

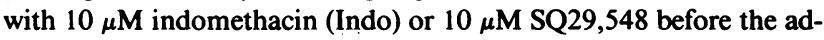
dition of medium alone or $0.1 \mu \mathrm{M}$ ET-1. The cells were then incubated for an additional $30 \mathrm{~min}$, and the change in mesangial cell cross-sectional area during the entire 40-min incubation was measured as described in Methods. Data are from two to four separate experiments. indo, indomethacin.

II). Thus we conclude that in cultured rat mesangial cells, inhibition of cyclooxygenase or blockade of $\mathrm{TXA}_{2}$ receptors have no effect on ET-1-induced reductions of mesangial cell cross-sectional area, suggesting that $\mathrm{PGF}_{2 \alpha}$ and $\mathrm{TXB}_{2}$ do not mediate contraction induced by ET-1. In addition, even though indomethacin amplified basal contraction by mesangial cells, the amount of $\mathrm{PGE}_{2}$ produced subsequent to ETstimulated phospholipase $A_{2}$ activity was not sufficient by itself to dampen ET-1-induced contraction on collagen gels.

ET-1 potentiates $\beta$ adrenergic-stimulated accumulation of intracellular $C A M P$. Similar to the model for regulation of smooth muscle cell contraction (25), the concentration of intracellular cAMP is thought to be an important negative-feedback signal to dampen vasoconstrictor-induced mesangial cell contraction $(11-13,16)$. Thus we investigated whether ET-1 would stimulate cAMP accumulation in cultured mesangial cells. When added alone, $0.1 \mu \mathrm{M}$ ET- 1 failed to elevate intracellular cAMP (Fig. 5). Added in the presence of $0.1 \mathrm{mM}$ IBMX, which magnifies $1.0 \mu \mathrm{M}$ isoproterenol-stimulated cAMP 6.2 -fold $(189 \pm 17 \mathrm{fmol} / \mu \mathrm{g}$ protein per $3 \mathrm{~min}$ without IBMX vs. $1,169 \pm 67$ with IBMX, mean \pm SEM, $n=4-6$ in duplicate), ET-1 modestly increased intracellular cAMP over basal levels (basal $=40 \pm 5$ vs. $0.1 \mu \mathrm{M}$ ET- $1=85 \pm 10$, mean \pm SEM, $n=5$ in duplicate). However, coincubation with ET-1 $(0.1 \mu \mathrm{M})$, in the absence of IBMX, nearly doubled isoproterenol-stimulated cAMP accumulation (Fig. 5). Ionomy$\operatorname{cin}(10 \mu \mathrm{M})$ and TPA $(0.1 \mu \mathrm{m})$, either alone or in combination, were unable to mimic the potentiation of cAMP synthesis by ET-1 (Fig. 5). Indeed ionomycin reduced isoproterenol-stimulated cAMP synthesis, which has been ascribed to $\mathrm{Ca}^{2+}$-mediated activation of phosphodiesterase (26). Neither TPA nor ionomycin affected basal cAMP levels. On the other hand, 10 $\mu \mathrm{M}$ indomethacin, which inhibits $>95 \%$ of cyclooxygenase activity in mesangial cells (24), had no effect on basal cAMP levels but blocked potentiation of isoproterenol-stimulated cAMP by ET-1 (Fig. 5). Addition of $\mathrm{PGE}_{2}$ to an extracellular concentration $(10 \mathrm{nM})$ similar to that stimulated by $0.1 \mu \mathrm{M}$ ET-1 (Fig. 4 B) mimicked the amplification of cAMP accumulation by ET-1. Similar amplification of cAMP accumulation was also observed when 0.1 and $1.0 \mathrm{nM} \mathrm{PGE}_{2}$ were coin- 


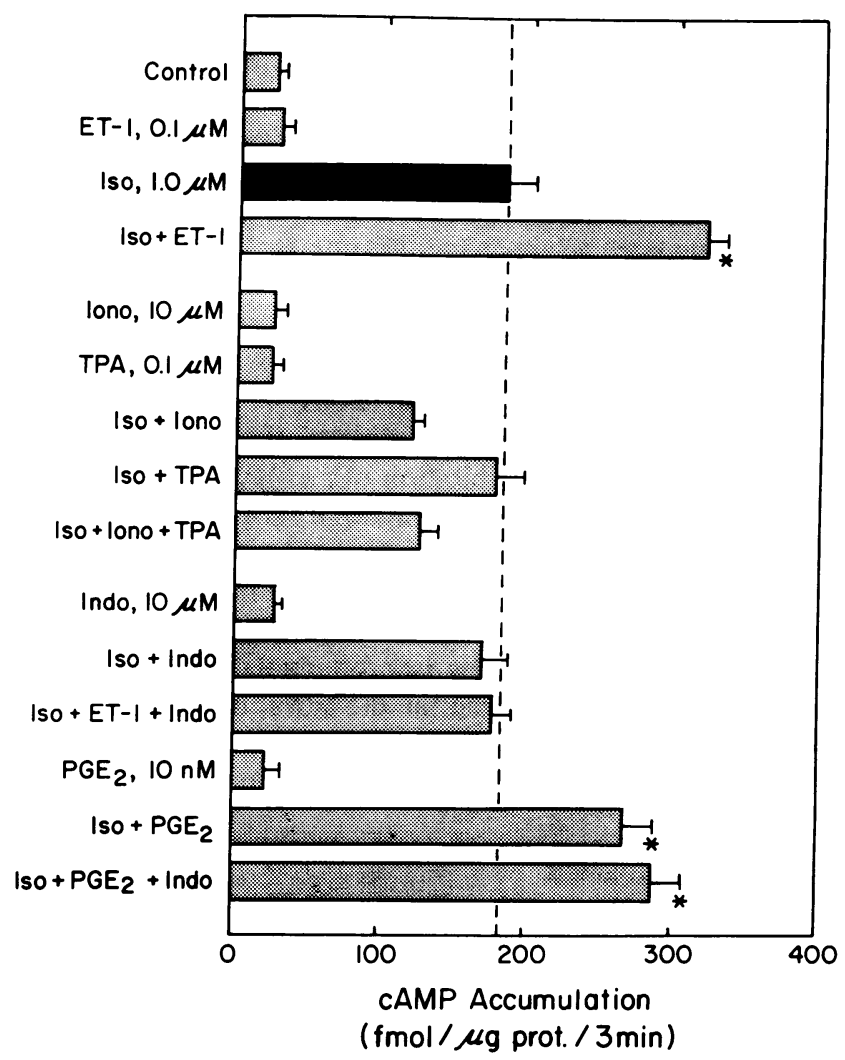

Figure 5. ET-1 amplifies isoproterenol-stimulated cAMP accumulation by a $\mathrm{PGE}_{2}$-dependent mechanism. Mesangial cells at $80 \%$ confluency in 12-well plates were washed and incubated for $3 \mathrm{~min}$ at $37^{\circ} \mathrm{C}$ in RPMI 1640 medium with $10 \mathrm{mM}$ Hepes, pH 7.4; IBMX was not used in these experiments. After extraction in $0.1 \mathrm{~N} \mathrm{HCl}$, radioimmunoassayable intracellular cAMP was measured after acetylation as described in Methods. The dashed line denotes cAMP accumulation in the presence of $1.0 \mu \mathrm{M}$ isoproterenol alone. Data are mean \pm SEM for four to seven experiments in duplicate. Abbreviations: Iso, isoproterenol; Iono, ionomycin; Indo, indomethacin. *Significantly different from $1.0 \mu \mathrm{M}$ isoproterenol values $(P<0.01)$ by Student's $t$ test.

cubated with ET-1. Coincubation with isoproterenol, $\mathrm{PGE}_{2}$ and indomethacin ruled out nonspecific interactions between adenylate cyclase and indomethacin. $10 \mathrm{nM} \mathrm{PGE}_{2}$ is below the threshold for activation of adenylate cyclase (Fig. 5 and reference 24), demonstrating that direct stimulation of adenylate cyclase by $\mathrm{PGE}_{2}$ did not account for the potentiating effect with isoproterenol. Thus these results suggest that an increase in $\left[\mathrm{Ca}^{2+}\right]_{i}$ and activation of protein kinase $\mathrm{C}$ do not mediate ET-1's potentiation of CAMP accumulation. Instead these data support the hypothesis that ET-1-stimulated $\mathrm{PGE}_{2}$ synthesis mediates amplification of $\beta$ adrenergic-stimulated cAMP accumulation by ET-1.

\section{Discussion}

There is accumulating evidence that the biological functions of ET-1 are of considerable importance in the kidney. ET-1 markedly increases renal vascular resistance and decreases renal blood flow, glomerular filtration rate, and $K_{\mathrm{f}}(5-10)$. In the rat $\mathrm{ET}-1$ at low doses modestly increases $\mathrm{NaCl}$ excretion (9) and decreases renin secretion from isolated glomeruli (27).
In the dog $\mathrm{ET}-1$ decreases $\mathrm{NaCl}$ excretion and increases plasma renin activity (8). We (14) and others (10) have shown that ET-1 is a potent mitogen for glomerular mesangial cells and that ET-1 evokes the phosphoinositide cascade. The present results demonstrate that ET-1 stimulates contraction of rat glomerular mesangial cells and increases $\mathrm{PGE}_{2}$ synthesis, which in turn potentiates $\beta$ adrenergic-stimulated cAMP accumulation. The increase in intracellular cAMP concentration could potentially dampen contraction in response to ET-1 to form a negative feedback loop $(11,25)$. Several lines of evidence suggest that ET-1-induced contraction is mediated by a $\mathrm{Ca}^{2+}$ signaling system activated by phospholipase $\mathrm{C}$. First, contraction in response to ET-1 occurred only at concentrations (i.e., $\geq 1.0 \mathrm{nM}$, see Table I and reference 14) that evoke a $\left[\mathrm{Ca}^{2+}\right]_{i}$ transient via activation of phospholipase $\mathrm{C}$ and the release of $(1,4,5) \mathrm{IP}_{3} .1 \mathrm{pM} \mathrm{ET}-1$, which generates only a modest increase of $\left[\mathrm{Ca}^{2+}\right]_{i}$ independent of phospholipase $C$ (14), failed to stimulate contraction. Second, when we mimicked the shape and magnitude of the ET-1-generated $\left[\mathrm{Ca}^{2+}\right]_{i}$ waveform with ionomycin, equal or greater numbers of cells contracted than with ET-1 (Fig. 2, Table I). Third, the inability of nifedipine to attenuate contraction in response to ET- 1 argues against a role for voltage-gated $\mathrm{Ca}^{2+}$ channels. Moreover, the minor $\left[\mathrm{Ca}^{2+}\right]_{\mathrm{i}}$ waveform in response to high concentrations of Bay K 8644 (Fig. 2), and the lack of contraction by cells incubated with Bay K 8644 (Table I), imply that under the present conditions mesangial cells express DHP-sensitive $\mathrm{Ca}^{2+}$ channels in low numbers or with diminished activity that are not functionally coupled to mesangial contraction. Using a different approach, Takeda and colleagues (28) reached similar conclusions regarding the role of voltage-gated $\mathrm{Ca}^{2+}$ channels in mesangial cell contraction in response to AVP. Fourth, staining with rhodamine-phalloidin revealed complex ET-1and $\mathrm{Ca}^{2+}$-mediated rearrangements of mesangial $\mathrm{F}$-actin microfilament bundles. These rearrangements resemble the transition from stationary cells elaborating thick stress fibers to motile cells exhibiting a diffuse meshwork state of actin microfilaments. Also, intense condensations of F-actin were observed contiguous to and parallel to the plasma membrane (Fig. 3, C, E, F, double arrows) where Latta (29) and Sakai and Kriz (30) in vivo, and Ausiello et al. (31) in vitro, previously documented extensive microfilament bundles (which resemble actomyosin complexes) by electron microscopy. Thus the available data support the hypothesis that activation of phospholipase $C$ and the subsequent mobilization of $\left[\mathrm{Ca}^{2+}\right]_{i}$ by Ins 1,4,5- $\mathrm{P}_{3}$ mediate ET-1-induced mesangial cell contraction.

In the present study, we employed mesangial cells cultured on three-dimensional, type 1 collagen gels to assess cell contraction. The use of a collagen substrate was prompted by reports showing that culture on or within type I collagen gels promotes expression of a contractile phenotype in isolated aortic myocytes (32) and bovine retinal microvascular pericytes (33). Mesangial cells on collagen gels expressed more abundant cytoplasmic extensions than cells on polystyrene, and these cells closely resemble the phenotype of mesangial cells in vivo $(29,30)$. In vivo these cytoplasmic extensions are dense with contractile filaments $(29,30)$ and are thought to play a vital function in the control of $K_{\mathrm{f}}$ by mesangial contraction $(11-13,16,30)$. ET-1-induced contraction occurred in the cell body but was pronounced in the cytoplasmic extensions and along the long axis of the cell (Fig. 1). The improved contractile response of mesangial cells cultured on type I col- 
lagen gels should facilitate investigations of mesangial contraction.

In the normal mesangium, $\mathrm{PGE}_{2}$ and $\mathrm{PGI}_{2}$, through stimulation of CAMP, help maintain renal function by counteracting the effects of vasoconstrictors on mesangial contraction (11-13, 16). Our experiments provide evidence for a novel mechanism by which ET-1 would elevate intracellular cAMP in mesangial cells. ET-1 stimulated $\left[{ }^{3} \mathrm{H}\right]$ arachidonate release and $\mathrm{PGE}_{2}, \mathrm{PGF}_{2 \alpha}$, and $\mathrm{TXB}_{2}$ synthesis consistent with ET-1 activation of phospholipase $A_{2}$. Similar activation of phospholipase $A_{2}$ by ET-1 was found by De Nucci et al. (4) who recently demonstrated that ET-1 released $\mathrm{PGI}_{2}$ and $\mathrm{TXA}_{2}$ in guinea pig and rat isolated lungs. Experiments with indomethacin and SQ29,548 suggested that $\mathrm{PGF}_{2 \alpha}$ and $\mathrm{TXB}_{2}$ do not mediate ET-1-induced mesangial contraction. Although the results with indomethacin support a role for $\mathrm{PGE}_{2}$ in attenuating basal contractillity, ET-1 failed to stimulate sufficient accumulations of $\mathrm{PGE}_{2}$ in culture to counteract the potent contractile activity of ET-1 (Table II). Likewise the concentration of $\mathrm{PGE}_{2}$ produced $(\sim 10 \mathrm{nM})$ in mesangial cells was insufficient to activate adenylate cyclase above basal levels (Fig. 5). The threshold for activation of adenylate cyclase by $\mathrm{PGE}_{2}$ is $\geq 100 \mathrm{nM}$ in cultured mesangial cells (24). In contrast, in the present experiments ET-1 nearly doubled cAMP production by isoproterenol (Fig. 5). Agonists that trigger the phosphoinositide cascade have been reported to potentiate $\beta$ adrenergic-stimulated cAMP accumulation by a protein kinase $\mathrm{C}$-dependent pathway $(26,34-36)$, although the biochemical mechanism remains unclear. For example, Nakiba et al. (37) have found that in vascular smooth muscle cells, angiotensin II amplifies cAMP accumulation stimulated by isoproterenol and vasoactive intestinal peptide. But in mesangial cells, ionomycin and TPA, alone and in combination, failed to mimic amplification of cAMP synthesis (Fig. 5), suggesting that an increase in $\left[\mathrm{Ca}^{2+}\right]_{\mathrm{i}}$ or protein kinase $\mathrm{C}$ activity did not mediate the potentiating effect ET-1. These results are similar to studies in guinea-pig cerebral cortical slices, where TPA and ionomycin failed to simulate histamine's ability to potentiate adenosine-stimulated cAMP accumulation (38). In contrast, indomethacin blocked amplification of cAMP accumulation in mesangial cells by ET-1, and addition of exogenous $10 \mathrm{nM}$ $\mathrm{PGE}_{2}$ restored the potentiation (Fig. 5). Because this concentration of $\mathrm{PGE}_{2}$ was insufficient to activate adenylate cyclase, the effect of $\mathrm{PGE}_{2}$ was not additive but potentiating. This pathway for potentiating CAMP accumulation contrasts with the view that direct activation of adenylate cyclase by $\mathrm{PGE}_{2}$ receptors accounts for the vasorelaxant properties of $\mathrm{PGE}_{2}(16$, 24). Thus it appears that $P_{G E}$ can elevate intracellular cAMP in mesangial cells by two distinct pathways: $(a)$ one pathway the result of direct activation of adenylate cyclase by $\mathrm{PGE}_{2} ;(b)$ the other due to potentiation by $\mathrm{PGE}_{2}$ of $\beta$ adrenergic-stimulated cAMP accumulation. It is interesting to note that potentiation by ET-1 approximately doubled the intracellular concentration of cAMP in the absence of IBMX (Fig. 5), whereas to achieve a doubling by direct activation required the addition of $>10 \mu \mathrm{M}$ exogenous $\mathrm{PGE}_{2}$ even in the presence of IBMX (24). Given the well-documented role of cAMP to dampen smooth muscle cell contraction (25), it seems possible that amplification of $\beta$ adrenergic-mediated cAMP accumulation by ET- 1 could attenuate ET-1-induced contraction, but this hypothesis remains to be tested.

The biochemical mechanism by which $\mathrm{PGE}_{2}$ amplifies $\beta$ - adrenergic-stimulated cAMP accumulation is at present unclear. Similar results were observed by Siegel et al. (39) in human platelets where $\mathrm{PGE}_{2}$ and $\mathrm{PGI}_{2}$, at concentrations insufficient to directly activate adenylate cyclase, markedly potentiate forskolin-stimulated cAMP synthesis. $\mathrm{PGE}_{2}$ and $\mathrm{PGI}_{2}$ increase both the efficacy and potency of forskolin as an activator of adenylate cyclase. Amplification by $\mathrm{PGE}_{2}$ of forskolin-stimulated cAMP synthesis has also been observed in brain slices $(40,41)$. Another possible mechanism would be inhibition of cAMP efflux by $\mathrm{PGE}_{2}, \mathrm{PGA}_{2}$, or $\mathrm{PGA}_{1}$. In certain cell types cAMP efflux is inhibited by $\mathrm{PGA}_{1}=\mathrm{PGA}_{2}>\mathrm{PGE}_{2}$ $\gg \mathrm{PGF}_{2 \alpha}(42-44)$, putatively via a glutathione conjugate of the prostaglandin (45). Thus inhibition of cAMP export by ET-1 could result directly from $\mathrm{PGE}_{2}$ or from $\mathrm{PGA}_{2}$ formed by the nonenzymatic hydrolysis of $\mathrm{PGE}_{2}$. In the present experiments, the net effect of reduced cAMP efflux on the intracellular concentration of cAMP would be enhanced when adenylate cyclase activity was elevated by isoproterenol. Further experiments are necessary to determine the site(s) of action for the potentiating effect of ET-1-induced $\mathrm{PGE}_{2}$ synthesis on $\beta$ adrenergic-stimulated cAMP accumulation in mesangial cells.

\section{Acknowledgments}

We gratefully acknowledge Dr. George Dubyak (Department of Physiology and Biophysics, Case Western Reserve University) for assistance with measurements of $\left[\mathrm{Ca}^{2+}\right]_{i}$. We also thank Julie Wolfe, Edith Hanzmann, and Jill Patterson for excellent technical assistance.

This work was supported by National Institutes of Health grants HL-22563 and HL-37117.

\section{References}

1. Yanagisawa, M., H. Kurihara, S. Kimura, Y. Tombe, M. Kobayashi, Y. Mitsui, Y. Yazaki, K. Goto, and T. Masaki. 1988. A novel potent vasoconstrictor peptide produced by vascular endothelial cells. Nature (Lond.). 332:411-415.

2. Itoh, Y., M. Yanagisawa, S. Ohkubo, C. Kimura, T. Kosaka, A. Inoue, N. Ishida, Y. Mitsui, H. Onda, M. Fujino, and T. Masaki. 1988. Cloning and sequence analysis of cDNA encoding the precursor of a human endothelium-derived vasoconstrictor peptide, endothelin: identity of human and porcine endothelin. FEBS (Fed. Eur. Biochem. Soc.) Lett. 231:440-444.

3. Yanagisawa M., I. Akihiro, T. Ishikawa, Y. Kasuya, S. Kimura, S. H. Kumagaye, K. Nakajima, T. Watanabe, S. Sakakibara, K. Goto, and T. Masaki. 1988. Primary structure, synthesis and biological activity of rat endothelin, and endothelium-derived vasoconstrictor peptide. Proc. Natl. Acad. Sci. USA. 85:6964-6967.

4. De Nucci, G., R. Thomas, P. D’Orleans-Juste, E. Antunes, C. Walder, T. D. Warner, and J. R. Vane. 1988. Pressor effects of circulating endothelin are limited by its removal in the pulmonary circulation and by the release of prostacyclin and endothelium-derived relaxing factor. Proc. Natl. Acad. Sci. USA. 85:9797-9800.

5. Tomobe, Y., A. Miyauchi, M. Saito, M. Yanagisawa, S. Kimura, K. Goto, and T. Masaki. 1988. Effects of endothelin on the renal artery from spontaneously hypertensive and Wistar Kyoto rats. Eur. J. Pharmacol. 152:373-375.

6. Lippton, H., J. Goff, and A. Hyman. 1988. Effects of endothelin in the systemic and renal vascular beds in vivo. Eur. J. Pharmacol. 155:197-199.

7. Wright, C. E., and J. R. Fozard. 1988. Regional vasodilation is a prominent feature of the haemodynamic response to endothelin in anaesthetized, spontaneously hypertensive rats. Eur. J. Pharmacol. 155:201-203.

8. Miller, W. L., M. M. Redfield, and J. C. Burnett. 1989. Inte- 
grated cardiac, renal, and endocrine actions of endothelin. J. Clin. Invest. 83:317-320.

9. King, A. J., B. M. Brenner, and S. Anderson. 1989. Endothelin: a potent renal and systemic vasoconstrictor peptide. Am. J. Physiol. 256:F1051-F1058.

10. Badr, K. F., J. J. Murray, M. D. Breyer, K. Takahashi, T. Inagami, and R. C. Harris. 1989. Mesangial cell, glomerular and renal vascular responses to endothelin in the rat kidney. J. Clin. Invest. 83:336-342.

11. P. Mene, M. S. Simonson, and M. J. Dunn. 1989. Physiology of the mesangium. Physiol. Rev. In press.

12. Schlondorff, D. 1987. The glomerular mesangial cell: an expanding role for a specialized pericyte. FASEB (Fed. Am. Soc. Exp. Biol.) J. 1:272-281.

13. Brenner, B. M., L. D. Dworkin, and I. Ichikawa. 1986. Glomerular ultrafiltration. In The Kidney. B. M. Brenner and F. C. Rector, editors. W. B. Saunders, Philadelphia. 124-144.

14. Simonson, M. S., S. Wann, P. Mené, G. R. Dubyak, M. Kester, Y. Nakazato, J. R. Sedor, and M. J. Dunn. 1989. Endothelin stimulates phospholipase $\mathrm{C}, \mathrm{Na}^{+} / \mathrm{H}^{+}$exchange, c-fos expression, and mitogenesis in rat mesangial cells. J. Clin. Invest. 83:708-712.

15. Berridge, M. J. 1987. Inositol trisphosphate and diacylglycerol: two interacting second messengers. Annu. Rev. Biochem. 56:159-193.

16. Dunn, M. J. 1987. Renal Prostaglandins. In Contemporary Nephrology. Vol. 4. S. Klahr and S. Massry, editors. Plenum Publishing Corp., New York. 133-194.

17. Simonson, M. S., and M. J. Dunn. 1986. Leukotriene $C_{4}$ and $\mathrm{D}_{4}$ contract rat glomerular mesangial cells. Kidney Int. 30:524-531.

18. Daniel, W. W. 1983. Biostatistics: A Foundation for Analysis in the Health Sciences. John Wiley, New York. 371-373.

19. Grynkiewicz, G., M. Poenie, and R. Y. Tsien. 1985. A generation of $\mathrm{Ca}^{2+}$ indicators with greatly improved fluorescence properties. J. Biol. Chem. 260:3440-3450.

20. Simonson, M. S., P. Mene, G. R. Dubyak, and M. J. Dunn. 1988. Identification and transmembrane signaling of leukotriene $D_{4}$ receptors in human mesangial cells. Am. J. Physiol. (Cell) 255:C771C780.

21. Bradford, M. M. 1976. A rapid and sensitive method for the quantification of microgram quantities of protein utilizing the principle of protein-dye binding. Anal. Biochem. 72:248-254.

22. Brooker, G., J. F. Harper, W. L. Terasaki, and R. D. Moyaln 1979. Radioimmunoassay of cyclic AMP and cyclic GMP. Adv. Cyclic Nucleotide Res. 10:1-33.

23. Bonventre, J. V., and M. Swidler. 1988. Calcium dependency of prostaglandin $E_{2}$ production in rat glomerular mesangial cells. $J$. Clin. Invest. 82:168-176.

24. Mené, P., and M. J. Dunn. 1988. Eicosanoids and control of mesangial cell contraction. Circ. Res. 62:916-925.

25. Kamm, K. E., and J. T. Stull. 1985. The function of myosin and myosin light chain kinase phosphorylation in smooth muscle. Annu. Rev. Pharmacol. Toxicol. 25:593-620.

26. Benovic, J. L., M. Bouvier, M. G. Caron, and R. J. Lefkowitz. 1988. Regulation of adenylyl cyclase-coupled $\beta$-adrenegic receptors. Annu. Rev. Cell Biol. 4:405-428.

27. Rakugi, H., M. Nakamaru, H. Saito, J. Higaki, and T. Ogihara. 1988. Endothelin inhibits renin release from isolated rat glomeruli. Biochem. Biophys. Res. Commun. 155:1244-1247.

28. Takeda, K., H. Meyer-Lehnert, J. K. Kim, and R. W. Schrier. 1988. Effect of angiotensin II on $\mathrm{Ca}^{2+}$ kinetics and contraction in cultured rat glomerular mesangial cells. Am. J. Physiol. 254:F254F266.
29. Latta, H. 1973. Ultrastructure of the glomerulus and juxtaglomerular apparatus. In Handbook of Physiology. J. Orloff, R. W. Berliner, and S. R. Geiger, editors. Williams and Wilkins, Baltimore. $1-29$.

30. Sakai, T., and W. Kriz. 1987. The structural relationship between mesangial cells and basement membrane of the renal glomerulus. Anat. Embryol. 176:373-386.

31. Ausiello, D. A., J. J. Kreisberg, C. Roy, and M. J. Karnovsky. 1980. Contraction of cultured rat glomerular cells of apparent mesangial origin after stimulation with angiotensin II and arginine vasopressin. J. Clin. Invest. 65:754-760.

32. Travo, P., P. Bodin, G. Burnstock, and J.-C. Stoclet. 1987. Quantitative method for the study of the morphological changes in duced by vasoactive agents in single aortic myocytes grown in primary cultures. Lab. Invest. 56:335-343.

33. Kelly, C., P. D'Amore, H. B. Hechtman, and D. Shepro. 1987. Microvascular pericyte contractillity in vitro. Comparison with other cells of the vascular wall. J. Cell Biol. 104:483-490.

34. Sibley, D. R., R. A. Jeffs, K. Daniel, P. Nambi, and R. J. Lefkowitz. 1986. Phorbol diester treatment promotes enhanced andenylate cyclase activity in frog erythrocytes. Arch. Biochem. Biophys. 244:373-381.

35. Yoshimasa, T., D. R. Sibley, M. Bouvier, R. J. Lefkowitz, and M. G. Caron. 1987. Cross-talk between cellular signaling pathways suggested by phorbol-ester induced adenylate cyclase phosphorylation. Nature (Lond.). 327:67-70.

36. Rozengurt, E., M. Murray, I. Zachary, and M. Collins. 1987. Protein kinase $C$ activation enhances cAMP accumulation in Swiss 3T3 cells. Inhibition by pertussis toxin. Proc. Natl. Acad. Sci. USA. 84:2282-2286.

37. Nakiba, T., Y. Nara, Y. Yamori, W. Lovenberg, and J. Endo. 1985. Angiotensin II and phorbol ester enhance isoproterenol- and vasoactive intestinal peptide-induced cyclic AMP accumulation in vascular smooth muscle cells. Biochem. Biophys. Res. Commun. 131:30-36.

38. Danoff, S. K., and J. M. Young. 1987. Is histamine potentiation of adenosine-stimulated cAMP accumulation in guinea-pig cerebral cortical slices mediated by products of inositol phospholipid breakdown? Biochem. Pharmacol. 36:1177-1179.

39. Siegel, A. M., J. W. Daly, and J. B. Smith. 1982. Inhibition of aggregation and stimulation of cyclic AMP generation in intact human platelets by the diterpene forskolin. Mol. Pharmacol. 21:680-687.

40. Seamon, K. B., W. Padgett, and J. W. Daly. 1981. Forskolin: a unique diterpene activator of adenylate cyclase in membranes and in intact cells. Proc. Natl. Acad. Sci. USA. 78:3363-3367.

41. Daly, J. W., W. Padgett, and K. B. Seamon. 1982. Activation of cyclic AMP generating systems in brain membranes and slices by diterpene forskolin: augmentation of receptor-mediated responses. $J$. Neurochem. 38:532-544.

42. Rindler, J. M., M. M. Bashor, N. Spitzer, and M. H. Saier. 1978. Regulation of adenosine $3^{\prime}: 5^{\prime}$-monophosphate efflux from animal cells. J. Biol. Chem. 253:5431-5436.

43. Brunton, L. L., and S. E. Meyer. 1979. Extrusion of cAMP from pigeon erythrocytes. J. Biol. Chem. 254:9714-9720.

44. Heasley, L. E., and L. L. Brunton. 1985. Prostaglandin $A_{1}$ metabolism and inhibition of cAMP extrusion by avian erythrocytes. J. Biol. Chem. 260:11514-11519.

45. Heasley, L. E., M. J. Watson, and L. L. Brunton. 1985. Putative inhibition of cAMP efflux: chromatography, amino acid composition, and identification as a prostaglandin $\mathrm{A}_{1}$-glutathione adduct. J. Biol. Chem. 260:11520-11524. 